\title{
Two decades of diplomatic representation of the Slovak Republic in the world - political-geographic perspective
}

\author{
Filip ŠANDOR, Daniel GURŇÁK
}

\begin{abstract}
The aim of the paper is political-geographical evaluation of the institutional representation of the Slovak Republic abroad. The geographical (complex) point of view on the foreign policy and localisation of the embassies significantly influence the way of understanding the nature of the network of diplomatic representation of the small state in central Europe. In the first section, we compare and evaluate government documents regarding the establishing, cancellation, or planning of the Slovak embassies in the world in three main periods. Subsequently, we compare official data with the real steps of diplomacy and the government of the Slovak Republic, especially in terms of time and space. In the next section, we point out the other diplomatic representations and their progressive increase. The last section identifies and defines the main factors affecting spatial changes in the localisation of the Slovak embassies abroad by most frequently mentioned reasons in government documents. We pointed out embassies and their effectiveness by economic relations, tourists and other factors. This article is a contribution to the Slovak political geography and the evidence of the undoubtable role of geography in foreign political decisions on the example of the embassy network of the Slovak Republic.
\end{abstract}

Keywords: Political Geography, Diplomatic Representation, Foreign Policy of the Slovak Republic

\section{Introduction}

Diplomacy has several tools to promote the interests of the state beyond its borders. One of them is the institutional aspect - diplomatic missions. Diplomatic missions, as a specific type of permanent state diplomatic bodies operating abroad, can currently perform a number of important diplomatic tasks. From political intelligence involving the continuous monitoring and analysis of the political situation in the receiving state, to promote business and investment contracts between business entities, and from the explanation and defence of the sending state's policies to the overall representation of the sending state in the receiving state (Pajtinka 2019). The presence of an embassy in a given country is not a matter of course and its establishment depends on a wide range of factors. The very presence of the embassy, the highest diplomatic office in the country, is of great importance for practicality, but also has a symbolic nature. In diplomacy, such an act is perceived as highly positive and favourable. The establishment of an embassy presupposes an increase in political dialogue, economic ties, and allround cooperation. By examining the spatial aspect of the location of the embassies of the Slovak Republic in the regions of the world, we will be able to understand the orientation of the foreign policy of Slovakia and identify changes in the network of embassies in time and space, and factors affecting these changes.

DOI: https://doi.org/10.33542/GC2020-2-06 


\section{Theoretical background}

The theoretical background of the research is linked to the neorealist approach of geopolitics and the assumption that the state plays a vital role in international relations and geopolitics, while space and distance enter into relations between states as important variables (Kofroň 2012). This study is also based on the initiative of the first geographical study on embassies of Slovakia published by Grác and Slavík in 2010. One of the many motivations was to continue and develop the topic of foreign policy within the framework of political geography.

As Grác and Slavík (2010) point out, the foreign policy issue involves a relatively wide range of problems. The differentiation of individual research is the result of a different aspect of the perception of the problem. In geography, such research is carried out mainly within the framework of political geography (Grác and Slavík 2010). Although several authors are involved in political geography in Slovakia, in addition to the above-mentioned pair of authors, only Gurńák, Blažík and Máriássyová (2014) dealt with the issue of diplomatic representation. Foreign policy issues were also analyzed by Buček (2006) and Ištok (2003). Detailed research by Pajtinka (2019) can be mentioned by non-geographic researchers.

Among foreign geographers and non-geographers, the foreign policy of the state was dealt within the context of diplomatic missions. According to Rose (2005), for example, bilateral trade with the state increases by about six to ten percent in connection with the establishment of a consulate in that state. Ferguson and Forslid (2019) also tested the effect of increasing trade by establishing or abolishing the embassies of Norway and Sweden. They concluded that the embassy plays an important role in increasing exports for medium-sized and also large companies. Bergeijk, Groot and Yakop (2011) elaborated an empirical study, which examined the effect of the embassy on bilateral trade in 63 countries using the gravitational model. The English geographer Neumayer (2008), using a multidimensional regression method, examined the bilateral patterns of the diplomatic representation of the world's states on the basis of three main factors: distance, state power and ideological kinship. Šumberová (2010) examined the localisation of embassies of the Czech Republic, Hungary, Poland and Slovakia in the world. Henrikson (2002) also deals with a foreign policy from a political-geographic perspective. He emphasizes the role and impact of distance on the foreign policy of the state, and examines three distance models that shape it. Vogeler (1995) investigated whether the Cold War geopolitics is reflected in the network of foreign embassies of the great powers and their allies. According to him, the existence or absence of diplomatic relations between countries and, in particular, the location of embassies, plays a decisive role and reflects the geopolitics of that time.

\section{Methods and data}

The data on embassies and consulates come from the Reports on the state of the network of embassies of the Slovak republic abroad, which are submitted by the Ministry of Foreign and European Affairs of the Slovak Republic (MFEA SR) to the Government of the Slovak republic irregularly. For this reason, only documents from 2001, 2003, 2004, 2005, 2007, 2008, 2012, 2013, 2015, 2018 are available. The irregularity of these reports indicates the very need for changes to the embassy network and consolidation after the 1990s, and consequently the adaptation of the network to the current geopolitical and economic realities in the world regions.

The analysed period 1999-2020 allows a more detailed comparison of development during six governments within two decades. Data from some years were supplemented from The Slovak Foreign Policy Yearbook (Brezáni 2007, 2011, 2012, 2015, 2017, 2018, 2019, Kotvanová 2000, 2003). By analysing the aforementioned official documents and expert publications, we have tried to identify the main factors influencing the localisation of embassies and the regions with the most noticeable changes. The identification of factors influencing the changes in the spatial layout of embassies was based on empirical research of formal documents. The detailed examination of the individual reports on the network of Slovak embassies was focused on the identification of key reasons for establishing or abolishing 22 specific embassies in the monitored 
period. The essence of the research was also to recognize the role of geographical factors in the reasons for the abolition or establishment of Slovak embassies. Some information and knowledge were drawn from interviews with some diplomatic staff at the MEFA SR.

\section{The development of the network of the Slovak diplomatic representation}

Slovakia has its diplomatic representation at the level of embassies on all continents. The average number of these offices during the 20 years examined was 61 . If the state does not have its embassy in the country, the diplomatic representation of such a country is usually handled by an accreditation of that territory under another Slovak embassy, usually in the nearest state where such embassy is already located.

In connection with the division of the assets of the Czechoslovak Federation, which also included assets abroad, Slovakia was able to open its embassies in 53 countries of the world and four permanent missions to international organizations as early as 1993 (Grác and Slavík 2010). For this reason, after the geopolitical changes and the end of the Cold War, the embassy network was uneven and did not correspond to the actual needs of independent Slovakia. Therefore, the embassies in Venezuela, Nicaragua, Costa Rica, and the consulate general in Padua were phased out after 1993 (Grác and Slavík 2010). Since 1999, Slovak embassies have been operating continuously in 50 countries. In addition, during the period under review, there were changes in activity and location at 22 embassies (tab. 1). Global spatial differentiation of embassies is currently uneven but corresponds to Slovak foreign policy priorities. From a total of 65 embassies (2020), 36 are located in Europe. There are 17 embassies in Asia, 6 in America, 5 in Africa and 1 in Australia. By comparison, in 2019 the Czech Republic had 90 embassies, Poland 88, Hungary 86, Austria 80, Finland 70, Denmark 67, Ireland 66, Slovenia 41 and Lithuania 40. Slovakia is 18th in the number of embassies from all EU countries (Lowy Institute 2019).

Tab. 1. Changes in the location of Slovak embassies during the three investigated periods (established - no colour, cancelled-grey colour)

\begin{tabular}{|cc|cc|cc|}
\hline \multicolumn{2}{|c|}{ 1999-2004 } & \multicolumn{2}{c|}{ 2005-2010 } & \multicolumn{2}{c|}{ 2011-2020 } \\
\hline \multirow{2}{*}{ Embassy } & $\begin{array}{c}\text { Year of } \\
\text { change }\end{array}$ & \multirow{2}{*}{ Embassy } & $\begin{array}{c}\text { Year of } \\
\text { change }\end{array}$ & Embassy & $\begin{array}{c}\text { Year of } \\
\text { change }\end{array}$ \\
\hline Riga & 2000 & Sarajevo & 2005 & Kuala Lumpur & 2012 \\
Kuala Lumpur & 2002 & Skopje & 2009 & Damascus & 2013 \\
Lima & 2003 & Tirana & 2009 & Chisinău & 2013 \\
Harare & 2003 & Hanoi & 2009 & Baghdad & 2014 \\
Abu Dhabi & 2004 & Addis Ababa & 2010 & Beirut & 2014 \\
Algiers & 2004 & Podgorica & 2010 & Tbilisi & 2014 \\
Hanoi & 2004 & Tripoli & 2010 & Abu Dhabi & 2014 \\
Santiago de Chile & 2004 & & & Baku & 2019 \\
Nur-Sultan & 2004 & & & Yerevan & 2020 \\
Kuwait & 2004 & & & & \\
\hline
\end{tabular}

Source: MFEA SR (2008, 2013, 2014-2018)

The first period of 1999-2004 is characterized by gradual consolidation and optimization of the embassy network (fig. 1). Slovakia's efforts to join the EU and NATO resulted in the realization of geographical and financial optimization. In 2003, an effort was made to secure an embassy in each EU member state (MFEA SR 2003). This objective has not been met to date and later proved not to be fully justified for reasons of efficiency, the scope of the staff agenda and, last but not least, the financial security of the office. One example was the long-term effective representation of the three Baltic states of Estonia, Latvia and Lithuania from the embassy in Riga (since 2012 Estonia has been under the embassy in Helsinki). However, such an accumulation of trade-economic and political agendas on the small number of embassy staff is concentrated on embassies located mainly in the Third World, where "Slovakia has no central 
political and economic interests - e.g., Harare and Santiago de Chile" (MFEA SR 2001a). However, these embassies were later closed completely in the framework of optimization. Consequently, this logically led to a reduction of Slovak representations in Latin America and Africa only to the largest of these continents. Slovakia has no significant interests in Latin America. This is affected and limited by distance and small economic ties. Since 2004, there has been a stable network of embassies in the region, without the need for enlargement, with spatially anomalous relations with Cuba as a small state in this region. However, Cuba covers a further 13 Caribbean states. The stable operation of our embassy in Havana is evidence that cooperation with Cuba has continued since the Cold War. It is noteworthy that Slovakia has the most intensive political relations in terms of the number of government visits and bilateral agreements from all over Latin America with Cuba (Šandor and Gurňák 2019).

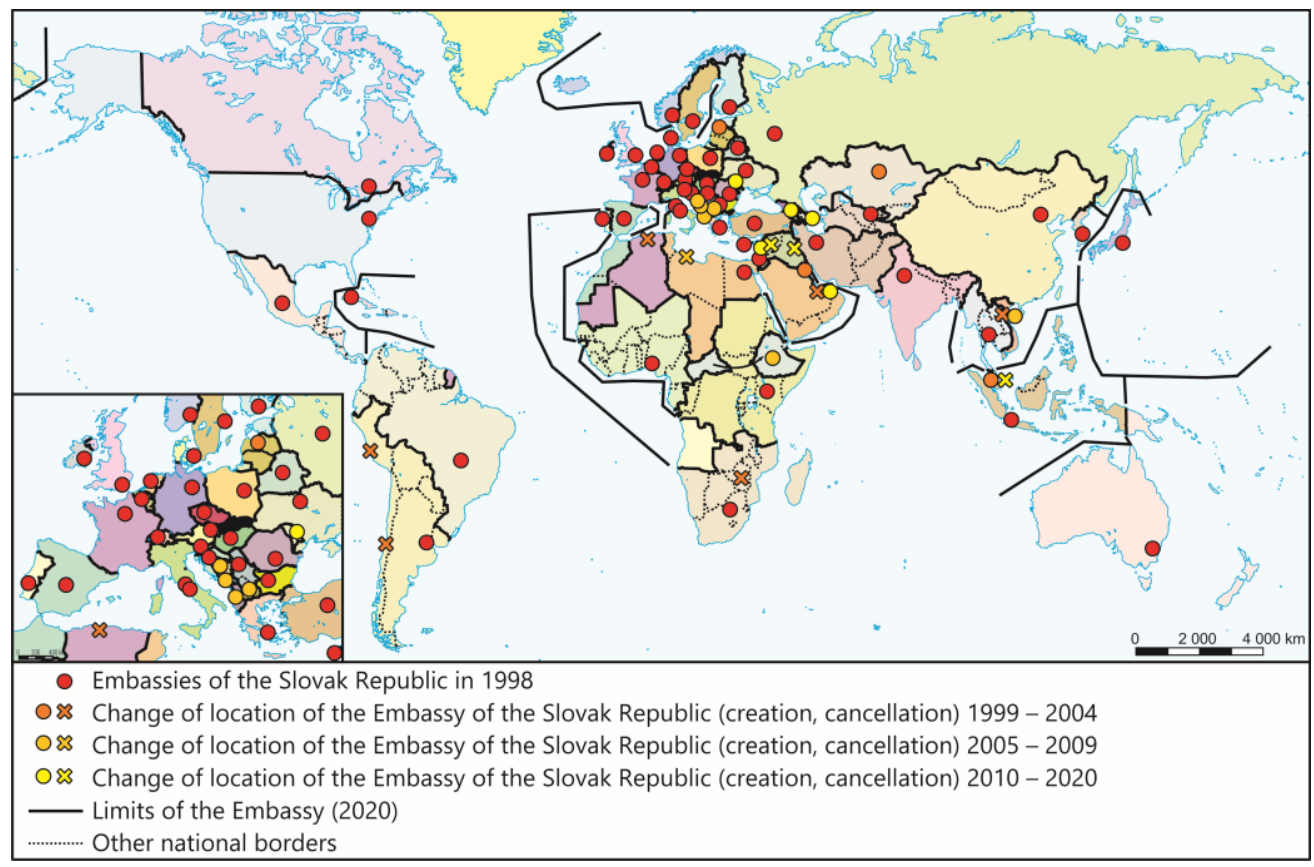

Fig. 1. The spatial differentiation of the embassies of the SR in the world; Source: MFEA SR (2008, 2013, 2014-2018)

Africa (especially Sub-Saharan Africa) is also not of big interest for the Slovak foreign policy. In addition to development and economic cooperation, Slovakia has no defined priority objectives and interests in this region. According to government documents, the embassy network was excessive in some regions - Latin America, South-East Asia but absent in others CIS countries and Middle East (MFEA SR 2003).

In Central Asia, Slovakia had a stable embassy in Tashkent, but it was missing in Kazakhstan, which was covered from Moscow. Kazakhstan's growing trade volume and economy led to a government decision to set up a full-fledged diplomatic representation in Nur-Sultan in 2004. The establishment of the embassy in Kuwait was justified by the business and high revenues of the seasonal consular office there for the visa-consular activity (high number of tourists from Kuwait visited mainly Slovak spas - particularly Piešt’any) (MFEA SR 2003). In contrast to small Kuwait, it is interesting that Slovakia has not yet developed bilateral relations with Saudi Arabia as a regional power in this area, to such a level as to establish an embassy there. Saudi Arabia was covered by the Embassy in the United Arab Emirates (UAE). The plan was to establish a direct diplomatic representation in Riyadh by 2005 and then close 
it in Abu Dhabi. Indeed, the embassy was closed in the Emirates, but it has not yet been opened in Riyadh (MFEA SR 2003). For about 10 years, the embassy in Cairo was covering almost the entire Arabian Peninsula. The development of bilateral relations with Saudi Arabia is slow and mostly depends ultimately on the willingness of the other party. It is also worth mentioning the financial demands and conditions for setting up an embassy in that country.

Formal government documents divide Africa into Sub-Saharan and Maghreb. In the Maghreb, Slovakia planned to close embassies in Algiers and Tripoli in period 1999-2004, and to merge the areas administrated by the individual embassies into one covered by the embassy in Morocco which was the most economically significant Slovak partner. The plans were not fully implemented as the embassy in Algeria was closed but the one in Tripoli persisted until the outbreak of the so-called Arab Spring and the civil war in Libya in 2011. This constituted another geographical anomaly. The embassy in Tripoli was the only one in the region except for Cairo, even though Libya outnumbered other states only in terms of oil and gas. The importance of this embassy was also confirmed by the organization of the visit of Prime Minister R. Fico to Libya in 2007. In addition to economic factors, which were not very important for Slovakia (oil from Libya was not imported), relations from the past, when Czechoslovakia provided Gaddafi extensive assistance both economically and especially in the security sphere (supplies, weapons and materials, staff training) were decisive. Most of the debt claims of Libya against the CSSR and aliquot against Slovakia came from this time. Here we can find the reason for the Slovak Prime Minister's visit. In terms of diplomatic coverage, this position of Libya may be similar to Cuba.

According to the plans of the Slovak Government to establish embassies in Georgia (2004), Albania (2004), Malaysia (2001), Kuwait (2003), Morocco (2003) and Saudi Arabia (2004) (MFEA SR 2001a), they were only set up in Kuala Lumpur and Kuwait. Embassies in Zimbabwe, Peru, UAE, Algeria, Vietnam and Chile were terminated due to the efficiency and slimming of the embassy network in the Third World (MFEA SR 2004). Thus, in the first period analysed, the number of embassies dropped to 58 .

During the second research period 2005-2010, there was a change of government and conditions created by Slovakia's integration into the EU and NATO, reflecting Slovak foreign policy interests in the regions of the world. Slovakia has defined geographical priorities of its foreign policy since 2005 (MFEA SR 2005). After cooperation with neighbouring states and the EU and NATO member states, is focused on developing relations and stabilizing the situation in the Western Balkans following the personal successes of Slovak diplomats in the service of international organizations, who were able to contribute significantly to the stabilization of the Western Balkans region. The report from 2007 discusses three priority directions for the development of the embassy network:

1) effective representation in the EU and NATO

2) to develop relations that are foreign and economic priorities of the Slovak republic

3) actively participate in the fulfilment of CFSP objectives (EU Common Foreign and Security Policy)

Slovak involvement in this area resulted in the fact, that four out of six embassies opened in period of 2005-2010, particularly 4 were established in this region. This region is not only a geographical priority of Slovakia outside the EU, but also a natural object of interest of the EU CFSP, as these countries have been the only in this region outside of the EU and NATO.

After the change of the Slovak government in 2006, trade relations with Vietnam intensified, resulting in the reopening of the embassy in Hanoi, which was abolished in 2004 for political, ideological and financial reasons (MF SR 2008). Official documents initially stated that after the opening of the embassy in Kuala Lumpur in 2002, there was a high density of our embassies in the region (MFEA SR 2003). Also, in 2008, the re-opening of the embassy in Abu Dhabi was discussed in just four years since its closure (MFEA SR 2008).

In contrast to the opening of embassies in comparable countries (by territory and population) in the Western Balkans, the opening of embassies in Lithuania and Estonia was still only 
considered during this period. It was planned to increase bilateral cooperation with Lithuania and Estonia and to coordinate mutual positions within the EU and NATO (MFEA SR 2007). Similarly, the opening of the embassy in Luxembourg has been considered since 2003 (MFEA SR 2003). From this, it can be concluded that in this period 2005-2010 the region of Western Balkans had a higher priority than the declared plan of Slovakia to establish an embassy in every EU Member State. The second phase of the development of the embassy network is characterized by an increase in embassies to a stable number of 63 .

During the third research period 2011-2020, the deterioration of the security situation in Libya caused the cancellation of the Tripoli embassy. The so-called "Arab Spring" and the emergence of the so-called Islamic State has destabilized the Middle East. This brought spatial changes in the network of embassies in the region. Following the cancellation of the embassies in Damascus and Baghdad, an embassy was established in Beirut. After 10 years, the embassy in Abu Dhabi was re-established. As planned, the Embassy in Kuala Lumpur was closed in 2012. It was the only Slovak embassy, which operated for only 10 years in the period under review. Firstly, this can be attributed to the aforementioned oversaturation of diplomatic representation in Southeast Asia, secondly to the existence of more priority regions in our foreign policy, and finally to the country's misjudged economic estimation. It can also be concluded that this embassy represented a substitute in the region for the embassy in Hanoi.

Georgia's convergence with the EU in connection with the signing of the Association Agreement made the cooperation with Slovakia more intensive. The establishment of the Slovak Embassy in Tbilisi was also supported by the fact that the Slovak Embassy in Moscow inefficiently covered the South Caucasus states. Georgia, Azerbaijan and Armenia are in the light of more attention by Slovakia, and after the last visit of Prime Minister P. Pellegrini to Baku in 2018 it was decided to establish embassies in Azerbaijan and Armenia. Slovakia's interest in the region was supported by economic ( $80 \%$ of the GDP of the South Caucasus is creating in Azerbaijan) and energy factors (MFEA SR 2018). At the end of 2019, the Slovak embassy was established in Baku and at the beginning of 2020 also in Yerevan (MFEA SR 2019a). The surprise in locating our embassy in small Armenia lies in the fact that only $11 \mathrm{EU}$ countries have their embassies in Yerevan (MFA AR 2020). The presence of an embassy in each of the three small states shows a significant increase in Slovak interests in the region. Slovakia also seems to have the ambition to acquire the role of mediator (as in the case of the Western Balkans). However, the former Minister of MFEA SR M. Lajčák commented on the recent location of the Caucasus embassies in three levels: it is a region that affects our security, Slovakia can provide its experience of the transition, it is an unexplored region in terms of our trade and economic interests (TASR 2020).

The long-term objective of the Slovak Foreign Service was to establish the Slovak embassy in Kabul, which would significantly improve the conditions of the Slovak military presence in the country (MFEA SR 2013). However, the failure to set up the embassy so far has been justified by costly implementation and may become redundant in the future with the prospect of withdrawing NATO troops from the country. Long-term and almost implemented plans to establish an embassy in Tunisia were discontinued due to unrest in the country in 2013 (MFEA SR 2012).

In Europe, attention has been paid to Moldova, which has also emerged as a state seeking to move closer to the EU in the framework of the EU's Eastern Partnership. Slovak interest in establishing an embassy there in 2013 reflects mutual interactions in sharing transformation experiences (MFEA SR 2012).

\section{Other diplomatic representations}

In addition to the embassies, Pajtinka (2019) defines quasi-diplomatic representations ("masked diplomatic missions"). These are entities operating in the territory of a foreign state and de facto performing some diplomatic functions in the interest of a (sending) state but do not have the formal status of diplomatic missions. An important common feature of all these entities is also that they can be established by the sending state and operate only with the agreement of the receiving country (Pajtinka 2019). 
Slovakia has its specific offices in Kosovo and Taiwan. Slovakia does not officially recognize these states, but it has institutional representations in them. They are not called embassies and thus they do not officially represent political units. In Kosovo, the Liaison Office of the Slovak Republic in Pristina is located, which is a branch of the Embassy of the Slovak Republic in Belgrade. It contributes to the support of the overall development of the country (MFEA SR 2019b). The Liaison Office acts in the receiving state as a formally separate entity whose "diplomatic" staff is not officially accredited in the receiving state, so it is formally not authorized to carry out diplomatic or consular functions in relation to the receiving state (Pajtinka 2019). In Taiwan, the Slovak Economic and Cultural Office Taipei facilitates bilateral cooperation in the areas of trade, investment, culture, science and research while respecting the "One China" policy (MFEA SR 2019c). Since Slovakia has significant investment relations with Taiwan, it was necessary to establish an institution to facilitate economic cooperation. Localization of the office in Taipei is based on a certain pragmatic Slovak foreign policy and in the end, results in satisfaction on both sides - for the People's Republic of China resulting from the de-politicization of our relations with Taiwan and for Slovakia benefiting from economic and cultural relations with Taiwan. In the case of Kosovo, Slovakia applies the principle of non-recognition of unilaterally separated territories from the state.

General and honorary consulates, Slovak institutes and permanent missions to international organizations abroad complete the Slovak institutional representation. Consulates General are mainly located in larger cities outside the capital and especially in countries with a Slovak minority. Since 2009, Slovakia has eight Consulates General located in Békéscsaba, Istanbul, Krakow, Munich, New York, St. Petersburg, Shanghai and Uzhhorod (fig. 2).

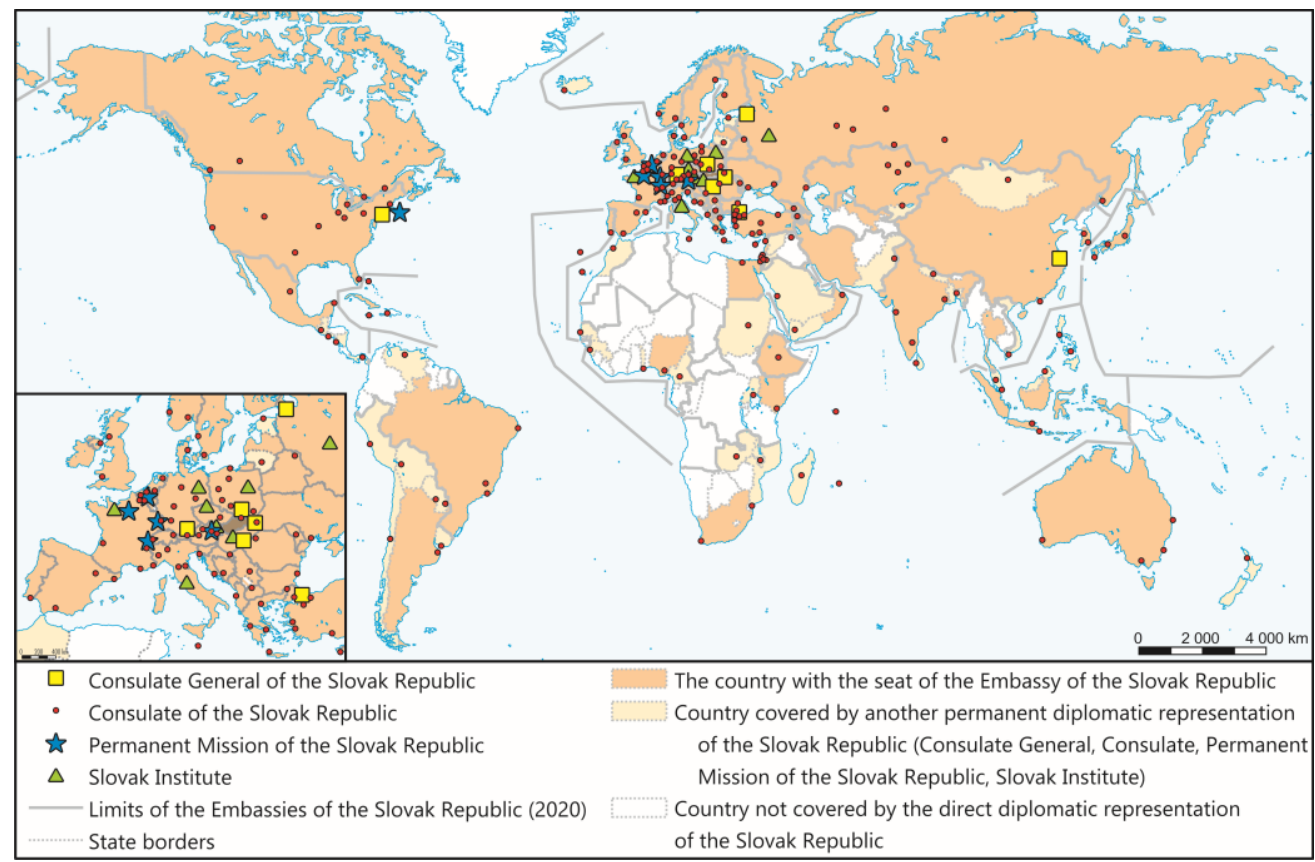

Fig. 2. The spatial differentiation of the other Slovak diplomatic representations in 2019; Source: (Brezáni 2019)

A consular office is a state authority permanently operating abroad, which is officially entrusted with the performance of consular functions in the defined territory of a certain foreign (receiving) state. Functions performed by a consular post are normally predominantly "non-political": providing assistance to citizens of the sending state in emergencies, notarial verification of various documents and signatures, arranging travel, identification and registry documents, or 
issuing visas to citizens of the receiving state (and possibly third countries). However, in certain specific circumstances, where diplomatic relations are absent between its sending and receiving states for political reasons, the consular post may also perform unofficially various diplomatic functions and thus act as a quasi-diplomatic representation of the State (Pajtinka 2019).

Scholars perceive Honorary consular offices (HCO) as a weaker sibling of diplomacy (Stringer 2011), which completes the network of state embassies. The Honorary Consul, unlike the General Consul, can also be citizens of the receiving states (even citizens of third countries) who make the good reputation of Slovakia and are involved in developing the country's relations with Slovakia. Most often, these offices are located and assisted in countries where Slovakia has no direct diplomatic representation. Consular officers have two main tasks. The first is the development of economic, promotional, scientific and cultural relations between countries. The second task is to ensure the interests of the sending country to a certain extent and services to citizens traveling or already present in the region of the country under which the consular post operates (Stringer 2011). The significance of honorary consulates is also evident because they can be professional and often less expensive than embassies.

Honorary consuls fund their activities from their own resources. They operate directly in the country's regions, which brings invaluable knowledge of the country's economic and cultural conditions (Stringer 2011). Therefore, the development of the number of Slovak honorary consulates was very progressive. While in 2001 Slovakia had 82 honorary consulates, in 2009 there were already 146 (Grác and Slavík 2010) and by 2019 their number grew to 186 in 100 countries across the world. These offices are spatially distributed more evenly than the embassies. This is due to efforts to locate them in the countries where Slovakia does not have direct diplomatic representation. Slovakia has $77 \mathrm{HCO}$ in Europe (45\% of total number of HCO), followed by Asia with 51 (26\%), America 35 (19\%), Africa 18 (10\%) and Australia and Oceania with 5 honorary consulates. More than one Slovak HCO is located in 32 countries. The largest numbers of the HCOs are in USA (11), Turkey (10), Poland (7) and Russia (7). In February 2015, the MFEA SR approved the document named "Proposal for the expansion of the Slovak HCO network led by honorary consular officers of the Slovak Republic until 2025", according to which the Slovak Consulate Network is to be approximately 320 HCO (MFEA SR 2019d). Further expansion of the HCO network is still justified mainly for their benefit in promoting Slovak interests, as well as for the increasing mobility of Slovak citizens and the necessity of ensuring consular assistance for travellers to countries where Slovakia does not have its embassies. A total of 53 HCO (MFEA SR 2019d) are responsible for issuing replacement travel documents. The latest HCO was opened in Jeddah, Saudi Arabia, in which Slovakia puts "hope that it will help to promote and present Slovakia to the Saudi public and business circles, thus helping Jeddah to become a springboard for the further development of relations between Slovakia and Saudi Arabia." (MFEA SR 2018).

Slovak institutes located in the capitals of eight European countries (Berlin, Budapest, Moscow, Paris, Prague, Rome, Warsaw and Vienna) ensure the Slovak cultural representation abroad. Slovakia is also represented in international organizations in the form of permanent missions. These are the Permanent Representation of the Slovak Republic to the EU and NATO in Brussels, the Permanent Mission of the Slovak Republic to the Council of Europe in Strasbourg, the OECD and UNESCO in Paris and the Permanent Mission to the UN in New York and Geneva (MFEA SR 2019e).

\section{Factors affecting the network of embassies of the Slovak Republic}

The very identification of the factors that have the greatest impact on the Slovak embassy network allows us to understand the changes in the spatial localization of the Slovak embassies. By analysing factors, it is easier to understand the dynamically changing international environment and to manage foreign policy more effectively. Grác and Slavík (2010) identified two main factors influencing the building of the network of embassies - Slovak foreign policy priorities and financial possibilities. Neumayer (2008) identified three factors affecting 
the deployment of embassies: geographical proximity, state power and ideological kinship. He also highlighted costs and political will as obstacles to setting up an embassy in the state. It can be agreed that the more analyses and factors are presented, the more and better the search for penetrations to achieve objective results will be sought.

The 2001 official report discusses 4 criteria on which the Slovak Foreign Service is based in completing the embassy network: the political and security interests (including the European transatlantic dimension of cooperation), economic interests, global interests and cultural interests. In 2005, the following factors were taken into account in the development of the network of business and economic departments of Slovak embassies (MFEA SR 2005):

1) political and economic stability of territories

2) dynamics of development of individual economies

3) geographical location and traditions

4) common or close commercial policy interests (e.g. V4 countries)

5) the absorption capacity of foreign markets.

The budget is one of the decisive factors affecting the network of foreign offices. Ensuring the operation of diplomatic offices and staff in nearly $200 \mathrm{UN}$ countries is costly, especially for small states (Stringer 2011). For example, according to the 2008 report, the establishment of embassies of the Slovak Republic in recent years was possible "...only at the cost of closing other offices. The decisive criterion for the development of the network was not the political or economic importance of the relation or the quality of services provided to citizens, but the allocated volume of funds from the state budget." (MFEA SR 2008). The volume of financial resources in 2018 continues to be a decisive and limiting factor in the development of the embassy network even after ten years (MFEA SR 2018). Reports on the state of the network of Slovak embassies in 2012, 2013 and 2015 stated that despite the lack of resources, the Slovak embassy network is able to realize the Slovak foreign policy interests on a professional level, but still is insufficient, not only in developing countries. The current volume of budgetary resources is a threshold for the sustainability of the network due to the extent and complexity of the tasks that are constantly placed on the department and does not create space for its further development (MFEA SR 2018). The former Slovak Minister of foreign affairs M. Lajčák declared that Slovakia has as many embassies as it can afford (TASR 2020). The issue of the budget for the spatial deployment of embassies is also important because the financial support of embassies represents $73 \%$ of the total budget of the MFEA SR (MFEA SR 2001b).

For this reason, it is necessary to examine the political and economic priorities of a given region and state for the needs of diplomacy and the establishment of diplomatic missions only where it is most effective and compatible with the financial and political needs of the state. The development of the budget of the MFEA SR can be seen in fig. 3. It was at its lowest in the years of the greatest impact of the global crisis. On the other hand, the highest values can be observed in 1998 when the capacity of foreign service increased after the change of government in Slovakia with the aim of integration into the EU and NATO and also during the Slovak Presidency in the Council of the EU in 2016.

"Foreign policy orientation in the context of world politics requires regular reflection on the definition of priorities" (Grác and Slavík 2010). Since 2004, the Slovak priorities have been adapted to the EU CFSP. In 2005, the spatial prioritization of the Slovak foreign policy was set out in four levels, which, according to some experts, also apply today (MFEA SR 2005):

1) relations with neighbouring countries

2) relations with EU and NATO countries

3) relations with Western Balkan countries and Eastern Europe

4) relations with other countries of the world.

At the last level, the greatest determinant was geographical distance and mutual trade, which reached a minimum share in the total volume of Slovakia (MFEA SR 2005). It can be agreed that the Western Balkans has long confirmed its leading role in our foreign policy priorities. Even 
with the network and density of embassies in the region, we can see a significantly higher level of involvement than, for example, in the Baltic States, which according to the strategy document should be more important for the Slovak foreign policy.

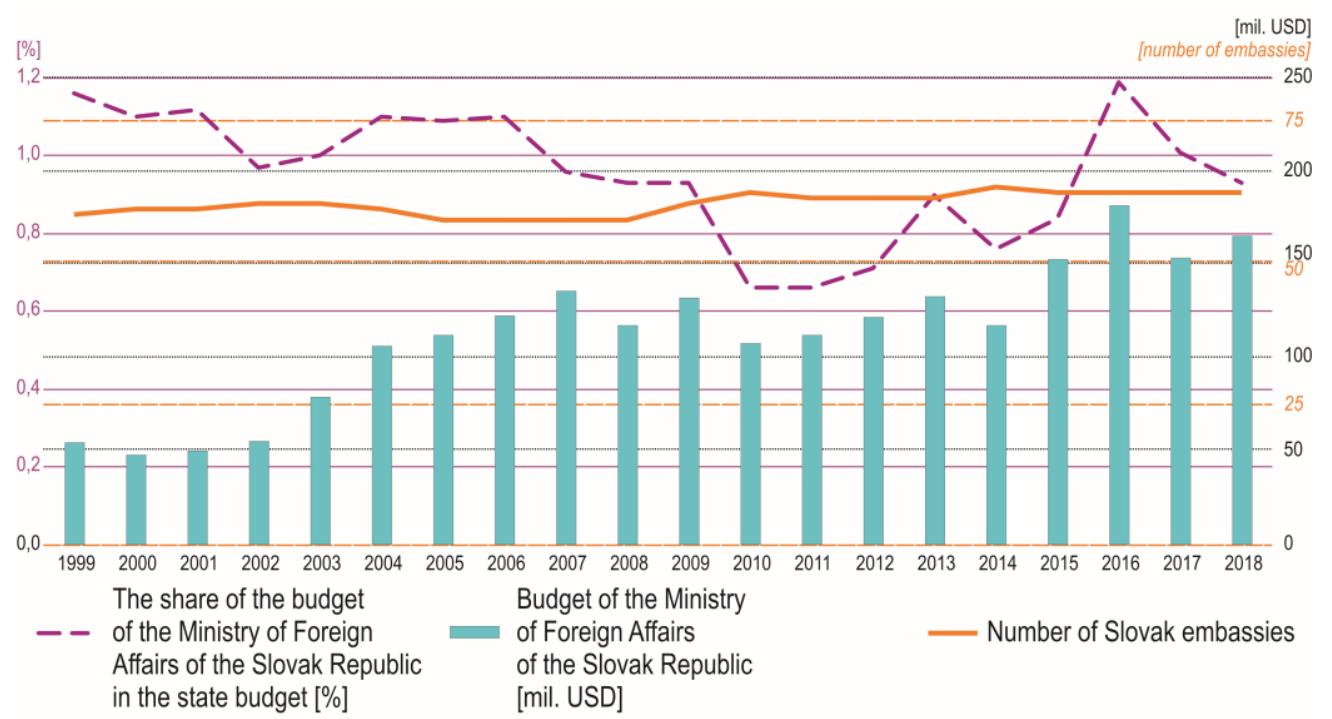

Fig. 3. Comparation of the number of embassies with budget dedicated to Ministry of the foreign and European affairs of the SR; Source: MFEA SR (2008, 2013, 2014-2018)

Ten years later, our analysis confirmed the budget and foreign policy interests as factors forming the network of Slovak embassies (Grác, Slavík 2010) are still valid, fundamental and inherent. Nevertheless, based on our analysis, other factors can be identified which are more or less independent of the two main ones and have a comparable impact on the development of the number and spatial orientation of the Slovak embassies.

Our own identification of factors affecting the network of embassies was based on an empirical examination of keywords to justify the establishment, cancellation, or planning of Slovak embassies in formal government documents. When mentioning the establishment, cancellation, or just thinking of changing the operation of the Slovak Embassy, the words, such as trade relations, foreign policy priorities, political reasons, security, distance, efficiency, slimming down, and financial possibilities have appeared (tab. 2.).

The survey suggests that the most frequently mentioned reasons for establishing embassies were trade-economic. The most mentioned factor for an embassy establishment was the interest of the EU as a whole. This can be stated when locating embassies in the Western Balkans, which is an EU priority and the most promising region for future integration. This is one of the reasons why Slovakia has gradually established embassies in Albania, Montenegro, Bosnia and Herzegovina, and Northern Macedonia. In the context of the EU CFSP, we can observe increased political interactions with the countries of the South Caucasus and the recent establishment of embassies in Georgia, Azerbaijan and Armenia. Foreign policy priorities are third (tab. 2), but economic and trade interests can be also considered as priorities or interests. This was followed by a few reasons such as financial reasons concerning the budget, then the efficiency of the representation, other reasons, security reasons in relation to the security situation in the country. For example, the change in the security situation in Libya has caused the closure of the embassy in Tripoli. The abolition and transfer of embassies from Damascus and Baghdad can also be attributed to this factor. Geographical reasons were mentioned by words such as "territory" or "region". Although explicitly mentioned only twice, they can be found indirectly at most embassies that have undergone a change over the entire period under review. 
Tab. 2. Factors affecting the formation of the Slovak embassy network

\begin{tabular}{|lc|}
\hline \multicolumn{1}{|c|}{ Factors } \\
\hline Key words & Count \\
\hline Economic/trade & 13 \\
EU (CFSP) & 8 \\
Priority/interests & 7 \\
Financial (budgetary) & 6 \\
Effectiveness & 5 \\
Other/not specifies & 5 \\
Security & 3 \\
Geographic & 2 \\
\hline
\end{tabular}

Source: MFEA SR (2008, 2013, 2014-2018)

At the same time, the trade-economic reasons for establishing embassies can be compared within a real bilateral trade volume. Economic factors are among the most important factors influencing the decision to establish an embassy or consulate in the country (Rose 2005, Neumayer 2008), which consequently positively influences the growth of the trade volume. Trade and economic factors can be observed in the establishing embassies, for example in Hanoi, Nur-Sultan, Azerbaijan (together with the EU CFSP) and the UAE. Fig. 4. shows that Slovakia has its embassies specifically in the countries with which it has the highest shares in mutual trade. With lower shares of mutual trade (below $0.10 \%$ ) prevails another factor of localisation of the embassy. We mainly talk about the overall size of the state or the strategic importance of the state in the region (especially in Africa and Latin America). Throughout the period under review, it can be seen that Slovak embassies covered countries with which Slovakia has more than $95 \%$ of total trade turnover. Taiwan has an interesting position, which is on average the 25th country on the list of countries with the top trade turnover. For this reason, the aforementioned quasi-diplomatic representation is located here to ensure Slovak business interests. It is also worth mentioning that Lithuania was among states without embassy with the largest share of turnover (around $0.14 \%$ ) in all research periods, while Latvia with the embassy had a slightly lower share in turnover.

The inefficiency of the placement of the embassy in Latvia can also be assessed through tourism in terms of incoming tourists to Slovakia. More than twice as many tourists come to Slovakia from Lithuania as from Latvia (MTC SR 2020). On the contrary, in Saudi Arabia and UAE, twice as many tourists come from the smaller UAE. The embassy in Kuwait was also justified by high financial gains from visas and consular services throughout the season (MFEA SR 2011-2018). This confirmed the number of visa applications to Slovakia from this country, which is ranked seventh of Asian countries that have a visa regime with Slovakia and annually applies for visas of around 600-700 Kuwaiti tourists (MI SR 2019). The income from consular and visa activities of the embassy is the ninth highest of all embassies and after Cairo, it is the second largest in the region of 54 thousand euros in 2019 (MFEA SR 2018). Even in 2011, Kuwait was the fourth most earning embassy due to visa services (if not counting cultural institutes). We also see the merit of the location of the embassy in fact that Slovakia does not have a visafree relationship with Kuwait and only six Asian countries have Slovak embassy and free-visa travel agreement (UAE, the Republic of Korea, Israel, Japan, Georgia and Taiwan). The question is whether Kuwait still requires Slovak embassy. Slovakia should consider if lower diplomatic representation (honorary or general consulate) would satisfy Slovak interests in Kuwait.

There is no doubt that spatial factors also play an important role in setting up a network of Slovak embassies (Rose 2005, Ferguson and Forslid 2019, Bergeijk, Groot and Yakop 2011, Neumayer 2008). It can be found in the form of distance or localization in the region. Distance affects the total volume of interactions of Slovakia and determines trade exchange. It can therefore be stated that in regions such as Latin America, Africa, Australia and Oceania, the Slovak embassies are only in the largest states of the regions. An exception can be seen in Cuba, which is an anomaly in a way mainly because its population and size do not fit into the imaginary 
pattern of embassies in America (Canada, USA, Mexico, Brazil, Argentina). The explanation must be found in a certain nostalgia and history of relations between aforementioned states.

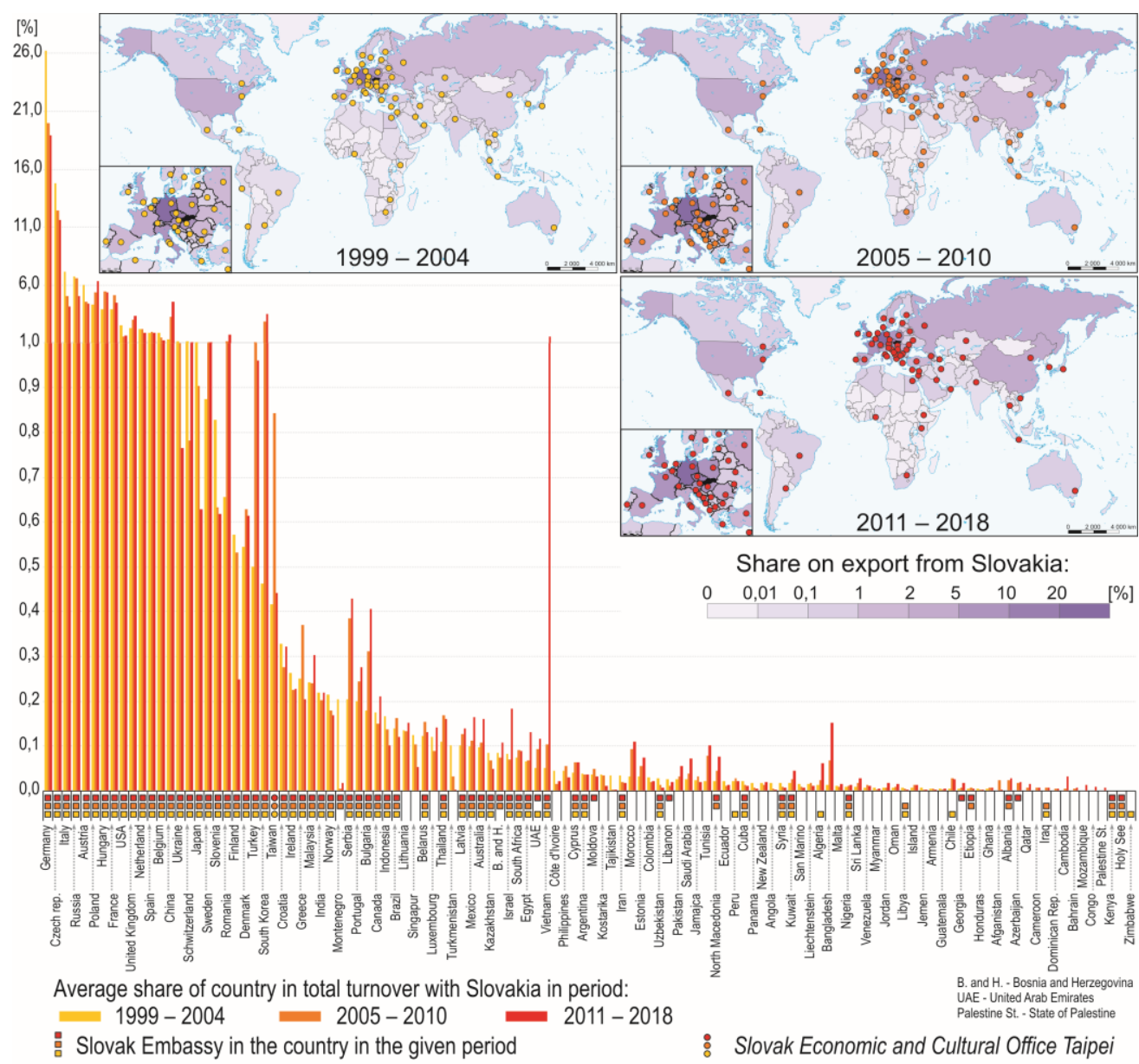

Fig. 4. The effectiveness of the embassies in relation to bilateral trade (export from Slovakia); Source: ME SR (2020)

The decision to locate the embassy is also influenced by the whole region. This is due to the earmarking of embassies geographically to cover their accreditation to countries in which Slovakia does not have an embassy. As an example, the Maghreb region, combined with the security factor, caused a long process of considering the location of the embassy from Tripoli first to Morocco, then to Tunisia. The aim was to create one embassy that would effectively cover the area of the francophone Maghreb (MFEA SR 2004). This factor can also be seen in the application to the largest states in Africa - Nigeria, South Africa, Kenya, Ethiopia. In this context, the cancellation of embassies in Peru, Chile, or Zimbabwe, is also linked to the transfer of competences to embassies in the largest states within the region (Brasilia, Argentina). The regional localization factor in connection with the trade-economic factor was also influenced by the cancellation of the embassy in Kuala Lumpur due to the oversaturation of embassies in Southeast Asia (MFEA SR 2003). In relation to geographical factors, it is interesting that in 2013 a transfer of a diplomat focused on economic diplomacy from Bangkok to Hanoi was planned due to Slovak interests and opportunities in using the importance of water management in the Mekong River Basin (MFEA SR 2013). 


\section{Conclusion}

In this article, we identified and evaluated spatial and temporal changes of Slovak diplomatic representation in the world, based mainly on the following study of Spatial aspects of the representative offices network in the context of the foreign policy of the Slovak Republic (Grác and Slavík 2010). We pointed out the relatively stable development of the number of institutional representations of Slovak diplomacy. This was more dynamic in their spatial aspect, with about a third of all allocated embassies in the world over the period 1999-2020 being affected by some changes. We have tried to identify the factors behind these changes (concerning the establishment, re-locating, cancellation, or planning embassy). We pointed out the role of geography in the location of embassies in the context of foreign policy.

This study brings a view of the regions with the greatest changes in the embassy's network. The most remarkable spatial changes in the network of diplomatic missions can be seen in the Middle East, Western Balkans, Southeast Asia and most recently in the South Caucasus region. Slovakia has the highest concentration of embassies in Europe and the smallest but "sufficient" in Latin America (MFEA SR 2003), if we do not consider Australia and Oceania. We pointed out the rapidly developing network of consular offices and the need for specific representations in Kosovo and Taiwan.

It is evident that the localization of Slovak embassies in some regions of the world does not fully correspond with the declared plans of the respective government. This may be due to ad hoc solutions, or to the prevalence of one type of factor over others. The fact remains that while Slovakia does not have an embassy in Saudi Arabia (a regional power), or in Lithuania, Estonia, Luxembourg and Malta (in the EU Member States), it has it in Northern Macedonia, Armenia, Kuwait, or the United Arab Emirates. The next question might be, how are those embassies really effective in relation to promoting tourism, trade, or investments?

In our analyses, we pointed out that the most mentioned factor by changing the status of the embassy was economic and trade priority. Then followed by the most frequently mentioned factors such as the Slovak membership in the EU and the CFSP of the EU. In this context, further integration within the EU will play an important role. In the future, the EU may substitute the diplomatic representations of the member states in the third countries (Vršanský, Valuch et al. 2016). However, in our opinion, this is not a topical issue of EU development at present and the state will continue to play a major role in creating its own embassy network.

The future development of the Slovak embassy network can be predicted on the basis of the earmarked factors. Security issues in the Middle East region will undoubtedly play a major role in these changes in the near future. We assume that the localization of the embassy to Saudi Arabia will also remain current, also in connection with Saudi Arabia's current efforts (2019) to open itself to tourism from non-Muslim countries by substantially simplifying visa procedures. The rapid development of economies in African and Asian countries will also be a determining factor in developing cooperation with these countries. For example, mutual trade indicators with Malaysia in the last two years show that it is realistic to think about re-establishing a certain representation in this country for the effective promotion of trade.

\section{References}

BERGEIJK, P.A.G., YAKOP, M., GROOT, L.F. 2011: The Economic Effectiveness of Diplomatic Representation: An Economic Analysis of its Contribution to Bilateral Trade. The Hague Journal of Diplomacy. 6(1-2). DOI: https://doi.org/10.1163/187119111X566751.

BREZÁNI, P. ed. 2007: Yearbook of Foreign Policy of the Slovak Republic 2006. Bratislava (Research Center of the Slovak Foreign Policy Association). Retrieved from: http://www.sfpa.sk/ wp-content/uploads/2014/02/Y2006.pdf.

BREZÁNI, P. ed. 2011: Yearbook of Foreign Policy of the Slovak Republic 2010. Bratislava (Research Center of the Slovak Foreign Policy Association). Retrieved from: http://www.sfpa.sk/ wp-content/uploads/2014/02/Y2010.pdf. 
BREZÁNI, P. ed. 2012: Ročenka zahraničnej politiky Slovenskej republiky 2011. Bratislava (Výskumné centrum Slovenskej spoločnosti pre zahraničnú politiku). Retrieved from: http://www.sfpa.sk/wp-content/uploads/2014/02/R2011.pdf.

BREZÁNI, P. ed. 2015: Ročenka zahraničnej politiky Slovenskej republiky 2014. Bratislava (Výskumné centrum Slovenskej spoločnosti pre zahraničnú politiku). Retrieved from: http://www.sfpa.sk/wp-content/uploads/2014/02/R2014.pdf.

BREZÁNI, P. ed. 2017: Yearbook of Foreign Policy of the Slovak Republic 2016. Bratislava (Research Center of the Slovak Foreign Policy Association). Retrieved from: http://www.sfpa.sk/ wp-content/uploads/2017/05/Rocenka_2016_web-1.pdf.

BREZÁNI, P. ed. 2018: Yearbook of Foreign Policy of the Slovak Republic 2017. Bratislava (Research Center of the Slovak Foreign Policy Association). Retrieved from: http://www.sfpa.sk/ wp-content/uploads/2018/04/Rocenka_2017_web985.pdf.

BREZÁNI, P. ed. 2019: Yearbook of Foreign Policy of the Slovak Republic 2018. Bratislava (Research Center of the Slovak Foreign Policy Association). Retrieved from: http://www.sfpa.sk/ wp-content/uploads/2019/04/Rocenka_2018_web.pdf.

BUČEK, J. 2006: Hlavné smery a problémy výskumu súčasnej politickej geografie. Geografický časopis. 58(4), 353-371.

FERGUSON, S., FORSILD, R. 2019: Sizing Up the Impact of Embassies on Exports. The Scandinavian Journal of Economics 121(1), 278-297. DOI: https://doi.org/10.1111/sjoe.12260.

GRÁC, R., SLAVÍK, V. 2010: Priestorové aspekty formovania siete zastupitel'ských úradov v kontexte zahraničnej politiky Slovenskej republiky. Geografický časopis. 62(3), 237-258.

GURŇÁK, D., BLAŽÍK, T., MÁRIÁSSYOVÁ, A. 2014: Meniaca sa geopolitická poloha Slovenska. In Lauko et al. ed. 2014: Regionálne dimenzie Slovenska. Bratislava (Univerzita Komenského v Bratislave), pp. 33-65.

HENRIKSON, A. 2002: Distance and Foreign Policy: A Political Geography Approach. International Political Science Review. 24(4), 437-466.

IŠTOK, R. 2003: Politická geografia a geopolitika. Prešov (Fakulta humanitných a prírodných vied Prešovskej univerzity v Prešove).

KOFROŇ, J. 2012: Geopolitika na pomezí geografie a mezinárodních vztahů: Mezi prostorem intersubjektivní a objektivním. Medzinárodní vztahy, 2012(2), 57-78.

KOTVANOVÁ, A. ed. 2000: Ročenka zahraničnej politiky Slovenskej republiky 1999. Bratislava (Slovenský inštitút medzinárodných štúdií). Retrieved from: http://www.sfpa.sk/wpcontent/uploads/2014/02/R1999.pdf.

KOTVANOVÁ, A. ed. 2003: Yearbook of Foreign Policy of the Slovak Republic 2002. Bratislava (Slovak Institute of International Studies). Retrieved from: http://www.sfpa.sk/wpcontent/uploads/2014/02/Y2002.pdf.

LOWY INSTITUTE 2019: Global diplomacy index. Sydney (Lowy Institute). Retrieved from: https://globaldiplomacyindex.lowyinstitute.org/country_rank.html.

ME SR 2020: Výsledky zahraničného obchodu. Bratislava (Ministry of economy of the Slovak Republic). Retrieved from: https://www.mhsr.sk/obchod/bilateralne-obchodne-vztahy/vysledky-zahranicneho-obchodu.

MF SR 2008: Návrh na zriadenie Zastupitel'ského úradu Slovenskej republiky v Hanoji, Vietnamská socialistická republika. Bratislava (Ministry of Finance of the Slovak Republic). Retrieved from: https://rokovania.gov.sk/RVL/Material/14583/1.

MFA AR 2020: Foreign representations in Armenia. Yerevan (Ministry of foreign affairs of the Republic of Armenia). Retrieved from: https://www.mfa.am/en/by-country/.

MFEA SR 2001a: Správa o stave siete zastupitel'ských úradov SR v zahraniči v r. 2001 a východiská pre jej d'alši rozvoj. Bratislava (Ministry of Foreign and European Affairs of the Slovak Republic). Retrieved from: https://rokovania.gov.sk/RVL/Material/3951/1. 
MFEA SR 2001b: Správa o vecnom a finančnom zabezpečení siete zastupitel'ských úradov Slovenskej republiky v zahraniční. Bratislava (Ministry of Foreign and European Affairs of the Slovak Republic). Retrieved from: https://hsr.rokovania.sk/data/att/73689_subor.rtf.

MFEA SR 2003: Správa o stave siete zastupitel'ských úradov SR v zahraničí v r. 2003 a východiská pre jej d'alši rozvoj. Bratislava (Ministry of Foreign and European Affairs of the Slovak Republic). Retrieved from: https://rokovania.gov.sk/RVL/Material/20594/1.

MFEA SR 2004: Správa o stave siete zastupitel'ských úradov SR v zahraničí v r. 2004 a východiská pre jej d'alši rozvoj. Bratislava (Ministry of Foreign and European Affairs of the Slovak Republic). Retrieved from: https://rokovania.gov.sk/RVL/Material/15289/1.

MFEA SR 2005: Správa o plnení úloh zahraničnej politiky SR v roku 2005. Bratislava (Ministry of Foreign and European Affairs of the Slovak Republic). Retrieved from: https://www.mzv.sk/ documents/10182/1635498/Aktu\%C3\%A1lny+ro\%C4\%8Dn\%C3\%BD+komponent+2005.pdf.

MFEA SR 2007: Správa o stave siete zastupitel'ských úradov SR v zahraničí v r. 2007 a východiská pre jej d'alši rozvoj. Bratislava (Ministry of Foreign and European Affairs of the Slovak Republic). Retrieved from: https://rokovania.gov.sk/RVL/Material/17057/1.

MFEA SR 2008: Správa o stave siete zastupitel'ských úradov SR v zahraničí vr. 2008 a východiská pre jej d'alši rozvoj. Bratislava (Ministry of Foreign and European Affairs of the Slovak Republic). Retrieved from: https://rokovania.gov.sk/RVL/Material/18578/1.

MFEA SR 2011-2018: Odvedené príjmy z konzulárnej a vizovej činnosti v roku 2011-2018. Bratislava (Ministry of Foreign and European Affairs of the Slovak Republic). Retrieved from: https://www.mzv.sk/ministerstvo/ministerstvo-zaverecny-ucet.

MFEA SR 2012: Správa o stave siete zastupitel'ských úradov SR v zahraničí v roku 2012 a východiská pre jej d'alší rozvoj. Bratislava (Ministry of Foreign and European Affairs of the Slovak Republic). Retrieved from: https://rokovania.gov.sk/RVL/Material/9043/1.

MFEA SR 2013: Správa o stave siete zastupitel'ských úradov SR v zahraničí v roku 2013 a východiská pre jej d'alši rozvoj. Bratislava (Ministry of Foreign and European Affairs of the Slovak Republic). Retrieved from: https://rokovania.gov.sk/RVL/Material/10445/1.

MFEA SR 2014-2018: Záverečný účet ministerstva za rok 2014-2018. Bratislava (Ministry of Foreign and European Affairs of the Slovak Republic). Retrieved from: https://www.mzv.sk/ ministerstvo/ministerstvo-zaverecny-ucet.

MFEA SR 2015: Správa o stave siete zastupitel'ských úradov SR v zahraničí v roku 2015 a východiská pre jej d'alš́ rozvoj. Bratislava (Ministry of Foreign and European Affairs of the Slovak Republic). Retrieved from: https://rokovania.gov.sk/RVL/Resolution/9031/1.

MFEA SR 2018: I. Korčok otvoril v saudskoarabskej Džidde honorárny konzulát SR. Bratislava (Ministry of Foreign and European Affairs of the Slovak Republic). Retrieved from: https://www.mzv.sk/cestovanie_a_konzularne_info/detail/-/asset_publisher/Iw1ppvnScIPx/content/i-korcok-otvoril-v-saudskoarabskej-dzidde-honorarny-konzulat-sr.

MFEA SR 2019a: Návrh optimalizácie siete zastupitel'ských úradov Slovenskej republiky v krajinách južného Kaukazu. Bratislava (Ministry of Foreign and European Affairs of the Slovak Republic). Retrieved from: https://rokovania.gov.sk/RVL/Material/23979/1.

MFEA SR 2019b: Styčný úrad Slovenskej republiky v Prištine. Bratislava (Ministry of Foreign and European Affairs of the Slovak Republic). Retrieved from: https://www.mzv.sk/web/ pristina/o_nas/nase_poslanie.

MFEA SR 2019c: Slovenský a ekonomický inštitút Taipei. Bratislava (Ministry of Foreign and European Affairs of the Slovak Republic). Retrieved from: https://www.mzv.sk/web/taipei/o_nas/nase_poslanie.

MFEA SR 2019d: Správa o stave siete zastupitel'ských úradov SR v zahraničí v roku 2018 a východiská pre jej d'alší rozvoj. Bratislava (Ministry of Foreign and European Affairs of the Slovak Republic). Retrieved from: https://rokovania.gov.sk/RVL/Material/23475/1. 
MFEA SR 2019e: Stále misie SR. Bratislava (Ministry of Foreign and European Affairs of the Slovak Republic). Retrieved from: https://www.mzv.sk/ministerstvo/slovenske_zastupitelstva-stale_misie.

MI SR 2019: Štatistický prehl'ad legálnej a nelegálnej migrácie v SR. Bratislava (Ministry of interior of the Slovak Republic). Retrieved from: https://www.minv.sk/swift_data/source/policia/hranicna_a_cudzinecka_policia/rocenky/rok_2019/2019-rocenka-UHCP-SK.pdf.

MTC SR SR 2020: Návštevníci v ubytovacích zariadeniach CR na Slovensku za rok 2019. Bratislava (Ministry of transport and construction of the Slovak Republic). Retrieved from: https://www.mindop.sk/ministerstvo-1/cestovny-ruch-7/statistika/ubytovacia-statistika/rok-2019.

NEUMAYER, E. 2008: Distance, power and ideology: diplomatic representation in a world of nation-states. Area, 40, 228-236. DOI: https://doi.org/10.1111/j.1475-4762.2008.00804.x.

PAJTINKA, E. 2019: Kvázidiplomatické zastúpenia a možnosti ich využitia vo vzt’ahoch medzi štátmi bez diplomatických stykov. Medzinárodné vzt’ahy, 17(4), 303-320.

ROSE, A. 2005: The Foreign Service and Foreign Trade: Embassies as Export Promotion. Berkeley (Haas School of Business, University of California). Retrieved from: http://faculty.haas.berkeley.edu/arose/revbureauc.pdf.

ŠANDOR, F., GURŇÁK, D. 2019: Priestorové dimenzie slovenskej zahraničnej politiky. In Gurńák, D. et al. eds. 30 rokov transformácie Slovenska. Bratislava (Univerzita Komenského v Bratislave), pp. 13-36.

STRINGER, D. K. 2011: Honorary Consuls in Small State Diplomacy: Through Liechtenstein's Lens. In Hooghe, I., Huigh, E. eds. Discussion papers in diplomacy. Netherlands (Institute of Interantional Relations 'Clingenadael'). Retrieved from: https://www.clingendael.org/sites/default/files/pdfs/20110200_cdsp_paper_kstringer.pdf.

ŠUMBEROVÁ, M. 2010: Diplomatická reprezentace jako indikátor Geopolitických preferencí. Geografie pro život ve 21. století. In Šumberová, M. eds. Sborník př́spěvků z XXII. sjezdu České geografické společnosti pořádaného Ostravskou univerzitou v Ostravě 31. srpna - 3. záŕí 2010. Ostrava (Ostravská univerzita v Ostravě). Retrieved from: http://konfeence.osu.cz/cgsostrava2010/dok/Sbornik_CGS/Politicka_a_kuturni_geografie/Sumbero va_Diplomaticka_reprezentace.pdf.

TASR 2020: CD CLUB: Minister Lajčák sa zrejme vráti do Bruselu, kde bude pracovat’ pre Európsku úniu. Bratislava (Tlačová agentúra SR). Retrieved from: https://tv.teraz.sk/cdklub/x7sm3n920200309_002_cd-klub_lajcak/17837/.

VOGELER, I. 1995: Cold war geopolitics: Embassy locations. Journal of Geography. 94(1), 323-329. DOI: https://doi.org/10.1080/00221349508979736.

VRŠANSKÝ, P., VALUCH, J. et al. 2016: Medzinárodné právo verejné. Osobitná čast'. Učebnica. Bratislava (Wolters Kluwer, Právnická fakulta UK).

\section{Authors' affiliations}

Mgr. Filip Šandor

Comenius University in Bratislava, Faculty of Natural Sciences,

Department of Regional Geography, Protection and Planning of the Landscape

Ilkovičova 6, 84215 Bratislava

Slovakia

filip.sandor@uniba.sk

doc. RNDr. Daniel Gurňák, PhD.

Comenius University in Bratislava, Faculty of Natural Sciences,

Department of Regional Geography, Protection and Planning of the Landscape

Ilkovičova 6, 84215 Bratislava

Slovakia

daniel.gurnak@uniba.sk 